Н. М. Серединська ${ }^{1}$, В. С. Хоменко ${ }^{1}$, О. М. Марченко ${ }^{1}$, К. С. Марченко-Толста ${ }^{2}$, Л. М. Киричок ${ }^{1}$

\title{
Моделювання артеріальної гіпертензії шляхом тривалого сольового навантанення. Моніторинг функціонування серцево-судинної системи та динаміки інтегральних показників життєдіяльності в щурів (частина II)
}

'Державна установа «Інститут фармакології та токсикології Національної академії медичних наук України», м. Київ

${ }^{2}$ Приватний вищий навчальний заклад «Київський медичний університет»

Ключові слова: артеріальна гіпертензія, моделі, сольове навантаження, серцевосудинна система, інтегральні показники

Аналіз літератури з питань моделювання артеріальної гіпертензії (АГ), що був висвітлений у попередній публікації [1], засвідчив доцільність розробки нової моделі АГ, на тлі якої можна було б вивчати тривалий вплив потенційних і впроваджених лікарських засобів різних фармакотерапевтичних груп, їхню ефективність та безпечність, гіпотензивну дію, механізм розвитку власне патологічного процесу тощо. На думку авторів, розвиток АГ не повинен супроводжуватися потужною стресорною реакцією, асоціюватися $з$ хірургічними втручаннями та/або введенням хімічних агентів або лікарських засобів, активацією певних медіаторних систем. Крім того, модель АГ повинна відрізнятися стабільністю, відтворюваністю, тривалістю патологічного процесу і розвиватися за одним з універсальних механізмів, що притаманний (певною мірою) АГ будь-якого генезу.

Однією 3 основних причин та/або ризику виникнення та розвитку АГ вважають надлишкове вживання натрію хлориду, що породжує рекомендацію щодо профілактики АГ - зниження надходження солі в організм [2, 3]. За відтворення будь-якої моделі АГ, як і за розвитку гіпертонічної хвороби різного генезу в людини, реєструється затримка натрію в організмі, що вва-

(c) Колектив авторів, 2019 жають спільною ланкою патогенезу цього захворювання [4-7]. Зазначені факти обгрунтовують доцільність розробки нової моделі АГ шляхом тривалого сольового навантаження, що перевищує 21 добу, термін описаної в літературі моделі сольової АГ для вивчення, зокрема, впливу лікарських засобів з різних фармакотерапевтичних груп за їхнього тривалого застосування, для дослідження механізмів розвитку АГ тощо.

Окреслені наукові відомості літератури, власні експериментальні та науково-аналітичні надбання дозволили нам висловити думку щодо необхідності продовження досліджень з вивчення функціонування серцево-судинної системи (та інших) за умов тривалого сольового навантаження, що перевищує термін 21 добу, описаної в літературі сольової («традиційної») моделі АГ. Результати експериментальних досліджень, наданих у наукових джерелах, не повною мірою висвітлюють дані щодо динаміки розвитку АГ, тобто характеру зміни артеріального тиску (AT) упродовж формування зазначеної моделі АГ (упродовж 21 доби). Чи $\epsilon$ стабільною модель АГ за сольового навантаження упродовж терміну, що перевищує 21 добу, невідомо. Даний факт обгрунтовує доцільність надання динамічних даних щодо АТ у білих щурів за щоденного моніторингу їхнього стану (зовнішнього вигляду, поведінкових і вегетативних реакцій, виживання 
тощо) упродовж рекомендованого терміну - 21 добу та за умов подовження сольового навантаження. Не визначено, які зміни функціонування серцевосудинної системи можуть відбуватися за умов подовження сольового навантаження (понад 21 добу). Інтерес до цих питань висвітлюється в сучасній науковій літературі [8]. Не встановлено, в якої кількості тварин за таких умов буде реєструватися (зберігатися або зникати) $\mathrm{A \Gamma}$, як змінюватиметься частота серцевих скорочень (ЧСС), які статеві відмінності будуть відзначатися за цих умов формування АГ. Така інформація, на нашу думку, сприятиме розширенню теоретичних знань щодо патогенезу АГ і може бути корисною для розробки більш досконалих моделей АГ, придатних для вивчення як механізму розвитку патологічного процесу, так і для дослідження ефективності та безпечності потенційних та існуючих лікарських засобів за їхнього тривалого застосування [9].

Мета дослідження - вивчити стан серцево-судинної системи та динаміку інтегральних показників життедіяльності в білих щурів за формування АГ шляхом тривалого сольового навантаження.

Матеріали та методи. Досліди проведено на статевозрілих нелінійних білих щурах обох статей 3 вихідною масою $(164,3 \pm 3,1)$ г $(\mathrm{n}=572)$, яких утримували на стандартному збалансованому раціоні харчування в віварії за умов вільного доступу до їжі та води, за температури $20-22{ }^{\circ} \mathrm{C}$ i відносної вологості 40-60 \%. Дослідження проведені з дотриманням вимог «Європейської конвенції з захисту хребетних тварин, які використовуються для експериментальних та інших наукових цілей» (Страсбург, 1986 р.).

Модель АГ («традиційну») відтворювали відповідно до загальноприйнятого методу сольового навантаження у вигляді пиття сольового розчину. Для цього застосовували $1 \%$ розчин натрію хлориду впродовж 21 доби за умов вільного доступу до нього. Оцінку стану серцево-судинної системи здійснювали шляхом визначення основних критеріальних показників. Реєстрацію АT і
ЧСС у щурів проводили до початку сольового навантаження (вихідні дані) i в динаміці впродовж формування АГ через 7, 14 і 21 добу від початку сольового навантаження 3 використанням сфігмоманометра (Ugo Basile, Італія).

За вищезазначеним обгрунтуванням і виходячи з мети дослідження, термін сольового навантаження подовжили ще на 60 діб. Вибір зазначеного терміну сольового навантаження зумовлений тривалістю численних системних запальних процесів або їхнім загостренням (наприклад, ревматичного походження), що можуть супроводжувати АГ, терміном лікування різних нозологій (наприклад, кардіальних патологічних станів), рекомендованим періодом застосування ліків різних фармакотерапевтичних груп, які можуть застосовуватися за АГ (наприклад, імуносупресори на тлі ревматичної та кардіальної патології) тощо. Таким чином, динамічну реєстрацію досліджуваних показників стану серцево-судинної системи (АТ, ЧСС), а також інтегральних показників життєдіяльності тварин (виживання, зовнішнього вигляду тварин, рухової активності, змін поведінки, здатності споживати воду та їжу, зоосоціальних відносин, здатності реагувати на зовнішні подразники (звукові, механічні), стану вегетативних функцій, больової чутливості) проводили в динаміці, загалом - упродовж 81 доби.

Больову чутливість у тварин визначали за тестом «tail flick» (подразнення проксимальної частини хвоста здійснювалося шляхом фокусування інфрачервоного променя), що оцінювалася за показником порога больової чутливості (ПБЧ, с; аналгезиметр Ugo Basile, Італія). Об'єм стопи реєстрували волюмометричним методом у динаміці протягом 81 доби.

Після акліматизації тварин (протягом 14 діб) у лабораторному приміщення та їхньої рандомізації сформовані відповідні групи щурів. До першої групи входили 10 щурів (група інтактних тварин; по 5 особин кожної статі), яких утримували в лабораторному приміщенні в клітках на звичайному режимі харчування за умов вільного доступу 
до їжі та води впродовж того самого терміну, як і тварин іншої групи. До другої групи віднесено тварин (562 щури), у яких шляхом сольового навантаження (сольове пиття 3 вільним доступом до нього впродовж 81 доби) викликали АГ.

Нормальність розподілу оцінювали за критерієм Shapiro-Wilk (W). Дані надані у вигляді середнього арифметичного та стандартної похибки репрезентативності середнього значення. Вірогідність між середніми значеннями у двох вибірках визначали за критерієм Стьюдента за нормального розподілу. Статистично значущими вважали відмінності за $\mathrm{p}<0,05$.

Результати та їх обговорення. На тлі формування «традиційної» АГ була зареєстрована загибель двох тварин (по одній кожної статі) з 562, які вживали сольовий розчин, що становило $0,36 \%$ (табл. 1). Загибель щурів зареєстрована на 23 і 24 добу від початку сольового навантаження за суттєвої втрати їхньої ваги. Однак, на нашу думку, закономірного характеру процес загибелі щурів на тлі формування АГ шляхом сольового навантаження не має, що повинно бути підтвердженим у процесі подальших досліджень.

За умов продовження терміну спостереження за тваринами понад 21 добу (тобто, на тлі вже сформованої АГ, що було засвідчено рівнем АТ), у деяких тварин з АГ зростали настороженість, збудженість, дратівливість, у всіх щурів знижувалася рухова активність (табл. 2).

Тремору, посмикування, судом, задухи не відмічалося в жодної тварини. У деяких щурів з АГ реєструвалися зростання частоти і глибини дихання та його аритмічність. Тонус хвоста, очних яблук, черева та кінцівок не змінювався упродовж терміну спостереження. Рефлекси повертання, розгинання, обіймання, а також больовий і рогівковий у тварин були збережені.

Інших ознак порушення показників життєдіяльності (агресивності, зміни реакції на зовнішні подразники, салівації, ринореї, птозу, екзофтальму, блефароспазму, кон'юнктивіту, а також зміни частоти дефекацій) у білих щурів за

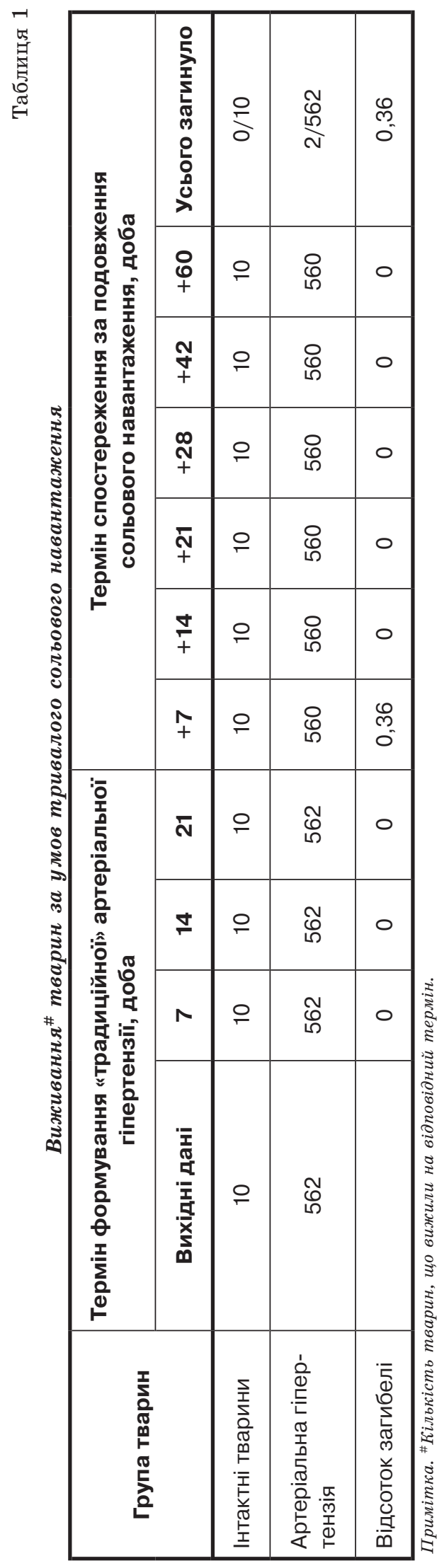


Таблиця 2

Зміни функиіонування органів і систем за наявністю (+/-) $i$ частотою (відсоток) клінічних симптомів за умов подовження сольового навантаження після 21 доби

\begin{tabular}{|c|c|c|c|c|c|c|c|c|}
\hline \multirow{2}{*}{$\begin{array}{l}\text { Клінічні } \\
\text { симптоми }\end{array}$} & \multicolumn{8}{|c|}{$\begin{array}{c}\text { Термін спостереження (доба) за подовження сольового } \\
\text { навантаження понад } 21 \text { добу }\end{array}$} \\
\hline & $\begin{array}{l}\text { Вихідні } \\
\text { дані }^{*}\end{array}$ & 7 & 14 & 28 & 35 & 42 & 49 & $56-60$ \\
\hline $\begin{array}{l}\text { Рухова актив- } \\
\text { ність тварин }\end{array}$ & - & $\begin{array}{c}\downarrow \\
(100 \%)\end{array}$ & $\begin{array}{c}\downarrow \\
(100 \%)\end{array}$ & $\begin{array}{c}\downarrow \\
(100 \%)\end{array}$ & $\begin{array}{c}\downarrow \\
(100 \%)\end{array}$ & $\begin{array}{c}\downarrow \\
(100 \%)\end{array}$ & $\begin{array}{c}\downarrow \\
(100 \%)\end{array}$ & $\begin{array}{c}\downarrow \\
(100 \%)\end{array}$ \\
\hline Тремор & - & - & - & - & - & - & - & - \\
\hline $\begin{array}{l}\text { Посмикування } \\
\text { тіла або кінцівок }\end{array}$ & - & - & - & - & - & - & - & - \\
\hline $\begin{array}{l}\text { Судоми, } \\
\text { посмикування }\end{array}$ & - & - & - & - & - & - & - & - \\
\hline Настороженість & - & $\uparrow \downarrow$ & $\uparrow \downarrow$ & $\uparrow \downarrow$ & $\uparrow \downarrow$ & $\uparrow \downarrow$ & $\uparrow \downarrow$ & $\uparrow \downarrow$ \\
\hline Збудженість & - & $\uparrow \downarrow$ & $\uparrow \downarrow$ & $\uparrow \downarrow$ & $\uparrow \downarrow$ & $\uparrow \downarrow$ & $\uparrow \downarrow$ & $\uparrow \downarrow$ \\
\hline Дратівливість & - & $\uparrow \downarrow$ & $\uparrow \downarrow$ & $\uparrow \downarrow$ & $\uparrow \downarrow$ & $\uparrow \downarrow$ & $\uparrow \downarrow$ & $\uparrow \downarrow$ \\
\hline $\begin{array}{l}\text { Дихання: } \\
\text { задуха, } \\
\text { зміна частоти, } \\
\text { зміна глибини, } \\
\text { неритмічне } \\
\end{array}$ & $\begin{array}{l}- \\
- \\
- \\
-\end{array}$ & $\begin{array}{l}- \\
\uparrow \\
\uparrow \downarrow \\
+ \\
+\end{array}$ & $\begin{array}{l}- \\
\uparrow \\
\uparrow \downarrow \\
+ \\
\end{array}$ & $\begin{array}{l}- \\
\uparrow \\
\uparrow \downarrow \\
+ \\
+\end{array}$ & $\begin{array}{l}- \\
\uparrow \\
\uparrow \downarrow \\
+ \\
\end{array}$ & $\begin{array}{c}- \\
\uparrow \\
\uparrow \downarrow \\
+ \\
+\end{array}$ & $\begin{array}{l}- \\
\uparrow \\
\uparrow \downarrow \\
+ \\
\end{array}$ & $\begin{array}{l}- \\
\uparrow \\
\uparrow \downarrow \\
+ \\
\end{array}$ \\
\hline $\begin{array}{l}\text { Ціаноз: кінцівок, } \\
\text { вушних раковин }\end{array}$ & & + & + & + & + & + & + & + \\
\hline $\begin{array}{l}\text { Тонус: хвоста, } \\
\text { очних яблук, } \\
\text { кінцівок, } \\
\text { черева }\end{array}$ & $\begin{array}{l}- \\
- \\
- \\
-\end{array}$ & $\begin{array}{l}- \\
- \\
- \\
-\end{array}$ & $\begin{array}{l}- \\
- \\
- \\
-\end{array}$ & $\begin{array}{l}- \\
- \\
- \\
-\end{array}$ & $\begin{array}{l}- \\
- \\
- \\
-\end{array}$ & $\begin{array}{l}- \\
- \\
- \\
-\end{array}$ & $\begin{array}{l}- \\
- \\
- \\
-\end{array}$ & $\begin{array}{l}- \\
- \\
- \\
-\end{array}$ \\
\hline $\begin{array}{l}\text { Рефлекси: } \\
\text { повертання, } \\
\text { рогівковий, } \\
\text { вушної раковини, } \\
\text { розгинання, } \\
\text { обіймання, } \\
\text { больовий }\end{array}$ & $\begin{array}{l}- \\
- \\
- \\
- \\
- \\
-\end{array}$ & $\begin{array}{l}- \\
- \\
- \\
- \\
- \\
-\end{array}$ & $\begin{array}{l}- \\
- \\
- \\
- \\
- \\
-\end{array}$ & $\begin{array}{l}- \\
- \\
- \\
- \\
- \\
-\end{array}$ & $\begin{array}{l}- \\
- \\
- \\
- \\
-\end{array}$ & $\begin{array}{l}- \\
- \\
- \\
- \\
- \\
-\end{array}$ & $\begin{array}{l}- \\
- \\
- \\
- \\
- \\
-\end{array}$ & $\begin{array}{l}- \\
- \\
- \\
- \\
- \\
-\end{array}$ \\
\hline
\end{tabular}

Примітка. (+/-) - Наявність/відсутність змін, $\uparrow \downarrow-$ посилення або послаблення реакцї в частини або в усіх (100\%) тварин даної групи, *вихідні дані відповідають терміну 21 доба від початку сольового навантаження.

умов тривалого сольового навантаження не відмічалося, у всіх тварин був охайний стан шерстного покриву та шкіри.

Фактично зміни інтегральних показників життедіяльності тварин за умов подовження терміну сольового навантаження понад 21 добу були аналогічними до тих, що спостерігалися в щурів за формування «традиційної» (до 21 доби) моделі АГ.

Упродовж перших 14 діб формування моделі АГ шляхом сольового навантаження дещо уповільнювалося зрос- тання маси тіла тварин порівняно 3 даним показником у тварин інтактної групи (табл. 3). У наступні терміни спостереження за подовження сольового навантаження не відмічалося зниження маси тіла щурів і реєструвався, фактично, фізіологічний приріст даного показника. За умов моделювання АГ (упродовж 21 доби), а також за подовження сольового навантаження (ще на 60 діб) не реєструвалися зміни коефіцієнтів маси внутрішніх органів, у тому числі тимуса. Стану тимуса приділяли 
особливу увагу з огляду на інформацію щодо порушення імунного статусу за умов АГ, а також дані, що свідчать про $\mathrm{AГ} \mathrm{як} \mathrm{запальний} \mathrm{процес.}$

Одним 3 важливих аспектів даної розробки $\epsilon$, на наш погляд, динамічне спостереження за функціонуванням серцево-судинної системи на тлі формування моделі АГ для розуміння механізму розвитку патологічного процесу, а також можливого визначення термінів для лікувального або профілактичного режимів застосування досліджуваних ліків.

Як свідчать дані таблиці 4 , у тварин за формування «традиційної» АГ спостерігалося підвищення АТ на 12,5$19,9 \%$ через 7-21 добу від початку сольового навантаження. Слід зазначити, що зі зростанням терміну сольового навантаження до 21 доби збільшувалася кількість тварин, у яких реєструвалося підвищення АТ. Так, через 7 діб після початку формування моделі $\mathrm{A} \Gamma$ у $56,6 \%$ білих щурів (у 318 з 562 тварин) АТ підвищився на 12,5\%. На 14 добу формування АГ у 66,6 \% тварин АТ підвищився на 21,7 \%. На 21 добу від початку сольового навантаження реєстрували 59,6 \% щурів (335 з 562 тварин) з підвищеним АТ на 13,8 \%. Саме цей термін є таким, що характеризує рівень АТ на тлі «традиційної» моделі АГ у білих щурів. За умов подальшого сольового навантаження 3 21 до 60 доби відзначалася значна кількість тварин з підвищеним АТ - 54,5$60 \%$ (305-336 щурів з 560). Водночас більше, ніж у 2 рази (до 23,6 \% ) знизилася кількість тварин з підвищеним АТ через 81 добу. За умов подовження сольового навантаження понад 21 добу відзначалося зростання АТ на 16,4 \% порівняно до вихідних даних через 28 діб від початку сольового навантаження, через 42 доби - на $13,4 \%$, через 60 діб - на 8,3 \%, через 81 добу - на 8,6 \%. Фактично, підвищення АТ спостерігалося загалом протягом усього терміну сольового навантаження - 81 добу.

Слід звернути увагу, що ступінь гіпертензії в усі терміни спостереження в самців був вищим, ніж у самиць. Особливо значущою зазначена відмінність була через 14, 60 і 81 добу від початку 
Артеріальний тиск у білих щурів за умов тривалого сольового навантаження,

Mм pm. $\mathrm{cm} .(M \pm m)$

\begin{tabular}{|c|c|c|c|c|c|c|c|c|}
\hline \multirow[b]{2}{*}{ Показник } & \multicolumn{8}{|c|}{ Термін спостереження, доба } \\
\hline & $\begin{array}{c}\text { Вихідні } \\
\text { дані }\end{array}$ & 7 & 14 & 21 & 28 & $42-45$ & $56-60$ & 81 \\
\hline $\begin{array}{l}\text { Артеріальний } \\
\text { тиск, мм рт. ст. } \\
\text { n }\end{array}$ & $\begin{array}{c}92,8 \pm \\
4,3 \\
562\end{array}$ & $\begin{array}{c}104,4 \pm \\
2,8^{\star} \\
318\end{array}$ & $\begin{array}{c}112,9 \pm \\
2,1^{\star} \\
374\end{array}$ & $\begin{array}{c}105,6 \pm \\
1,9^{\star} \\
335\end{array}$ & $\begin{array}{c}108,0 \pm \\
2,9^{\star} \\
336\end{array}$ & $\begin{array}{c}104,9 \pm \\
2,0^{\star} \\
305\end{array}$ & $\begin{array}{c}100,5 \pm \\
2,8^{\star} \\
305\end{array}$ & $\begin{array}{c}100,8 \pm \\
2,0^{\star} \\
132\end{array}$ \\
\hline $\begin{array}{l}\text { Зміна артеріаль- } \\
\text { ного тиску, \% }\end{array}$ & - & 12,5 & 21,7 & 13,8 & 16,4 & 13,4 & 8,3 & 8,6 \\
\hline $\begin{array}{l}\text { Кількість тварин з } \\
\text { артеріальною } \\
\text { гіпертензією\# }\end{array}$ & 0 & $\begin{array}{l}318 / \\
562\end{array}$ & $\begin{array}{l}374 / \\
562\end{array}$ & $\begin{array}{l}335 / \\
562\end{array}$ & $\begin{array}{l}336 / \\
560\end{array}$ & $\begin{array}{l}305 / \\
560\end{array}$ & $\begin{array}{l}305 / \\
560\end{array}$ & $\begin{array}{l}132 / \\
560\end{array}$ \\
\hline $\begin{array}{l}\text { Частота розвитку } \\
\text { артеріальної } \\
\text { гіпертензії, \% }\end{array}$ & 0 & 56,6 & 66,6 & 59,6 & 60,0 & 54,5 & 54,5 & 23,6 \\
\hline $\begin{array}{l}\text { Зміна артеріаль- } \\
\text { ного тиску в } \\
\text { самиць, \% } \\
(\mathrm{n}=290)\end{array}$ & $\begin{array}{c}95,2 \pm \\
3,7\end{array}$ & 17,3 & 18,1 & 15,8 & 14,4 & 10,9 & 9,6 & 12,0 \\
\hline $\begin{array}{l}\text { Зміна артеріаль- } \\
\text { ного тиску в сам- } \\
\text { ців, \% (n= 270) }\end{array}$ & $\begin{array}{c}89,8 \pm \\
4,7\end{array}$ & 20,5 & 36,2 & 20,9 & 16,2 & 14,2 & 19,8 & 27,0 \\
\hline
\end{tabular}

Примітка. *p < 0,05 порівняно з вихідним значенням, \#відношення кількості тварин з підвищеним АТ до загальної кількості щурів у групі.

сольового навантаження, коли значення АТ у самців вдвічі перевищували останні у самиць. Питання щодо механізмів розвитку АГ упродовж тривалого сольового навантаження з урахуванням статі тварин, характеру компенсаторних реакцій тощо потребують подальшого дослідження, принаймні, для удосконалення моделювання АГ.

Протягом формування «традиційної» моделі АГ (упродовж 21 доби) не реєстрували суттєвих змін частоти та ритму серцевих скорочень (табл. 5). У наступний період спостереження за тваринами з АГ за збереження сольового навантаження (до 81 доби) констатували факт зниження ЧСС (починаючи з 28 доби від початку вживання сольового розчину), що може бути свідченням залучення до патологічного процесу компенсаторних механізмів.

Як зазначалося вище, доцільність дослідження щодо функціонування різних органів і систем у щурів за умов

Таблиця 5

Частота сериевих скорочень у білих иурів за улов розвитку артеріальної гіпертензї, уд/хв $(M \pm m)$

\begin{tabular}{|c|c|c|c|c|c|c|c|}
\hline \multicolumn{8}{|c|}{ Термін спостереження, доба } \\
\hline Вихідні дані & 7 & 14 & 21 & 28 & $42-45$ & $56-60$ & 81 \\
\hline \multicolumn{8}{|c|}{ Інтактні щури, $n=10$} \\
\hline $368,7 \pm 4,3$ & $\begin{array}{c}370,1 \pm \\
8,4\end{array}$ & $\begin{array}{c}368,4 \pm \\
14,1\end{array}$ & $\begin{array}{c}370,7 \pm \\
4,3\end{array}$ & $\begin{array}{c}365,1 \pm \\
11,4\end{array}$ & $\begin{array}{c}368,4 \pm \\
14,1\end{array}$ & $\begin{array}{c}363,3 \pm \\
13,7\end{array}$ & $\begin{array}{c}372,3 \pm \\
11,2\end{array}$ \\
\hline \multicolumn{8}{|c|}{ Щури за сольового навантаження, $n=560$} \\
\hline $368,7 \pm 4,3$ & $\begin{array}{c}360,0 \pm \\
9,9\end{array}$ & $\begin{array}{c}373,0 \pm \\
4,7\end{array}$ & $\begin{array}{c}365,1 \pm \\
12,4\end{array}$ & $\begin{array}{c}326,3 \pm \\
2,4^{\star}\end{array}$ & $\begin{array}{c}321,5 \pm \\
5,3^{\star}\end{array}$ & $\begin{array}{c}322,9 \pm \\
10,8^{\star}\end{array}$ & $\begin{array}{c}328,7 \pm \\
10,2^{\star}\end{array}$ \\
\hline
\end{tabular}

Примітка. *p <0,05 порівняно з вихідним значенням і показниками в інтактних шурів. 
збереження сольового навантаження після формування АГ обгрунтована, зокрема, необхідністю вивчення впливу лікарських засобів за умов тривалого призначення. Нерідко препарати різних фармакологічних груп, що застосовуються для лікування АГ, спричинюють низку побічних реакцій, серед яких набряки кінцівок, обличчя. Часто АГ супроводжується больовим синдромом i набряком. Тому було доцільним проведення дослідження 3 визначення больової реакції в щурів, а також можливості розвитку набряку кінцівок за умов тривалого сольового навантаження.

Як свідчать дані таблиці 6, в інтактних тварин спостерігалися незакономірні та статистично не значимі зміни порога больової чутливості (ПБЧ). За формування АГ упродовж 21 доби відмічалося підвищення ПБЧ порівняно 3 вихідними даними на 27,9-30,0 \%, що є свідченням суттєвого зниження больового відчуття в білих щурів.

Упродовж наступного терміну спостереження за тваринами з АГ, які знаходилися в умовах сольового навантаження ще 60 діб, не спостерігалося більш суттєвих змін ПБЧ за ті, що були зареєстровані впродовж формування «традиційної» АГ (до 21 доби від початку сольового навантаження).
Таким чином, ПБЧ від 21 до 81 доби залишався суттєво підвищеним на 18,0-24,6 \% порівняно 3 вихідними даними в тварин зазначеної групи. Зростання ПБЧ упродовж усього терміну спостереження було також статистично значимим відносно значень у інтактних тварин.

Отже, у щурів за формування АГ упродовж 21 доби, а також за умов збільшення терміну сольового навантаження знижується больова чутливість.

Особливу увагу слід звертати на наявність набряків стопи в тварин за умов сольового навантаження. В інтактних тварин зареєстровано фізіологічні зміни об'єму стопи щурів, що зумовлені збільшенням віку впродовж майже тримісячного дослідження (табл. 6). Формування АГ за сольового навантаження впродовж 21 доби супроводжувалося збільшенням об’єму стопи порівняно з вихідними даними на 9,9-14,9\% . Водночас дані зміни були за ступенем прояву, фактично, аналогічними до тих, що реєструвалися в інтактних щурів, що може бути пов'язано зі зростанням маси (ростом) тварин. За подовження терміну сольового навантаження об'єм стопи поступово зростав i перевищував значення, що реєструвалися в тварин інтактної групи, майже на $16 \%$ через 81 добу від початку

Таблиця 6

Поріг больової чутливості і об’ел стопи в білих шурів за формування артеріальної гіпертензї шляхом тривалого сольового навантаження упродовж 81 доби $(M \pm m)$

\begin{tabular}{|c|c|c|c|c|c|c|c|c|}
\hline \multirow{2}{*}{ Показник } & \multicolumn{8}{|c|}{ Термін спостереження, доба } \\
\hline & Вихідні дані & 7 & 14 & 21 & 28 & $42-45$ & $56-60$ & 81 \\
\hline & \multicolumn{8}{|c|}{ Інтактні щури, $n=10$} \\
\hline $\begin{array}{l}\text { Поріг больової } \\
\text { чутливості, с } \\
\end{array}$ & $\begin{array}{c}9,39 \pm \\
0,30 \\
\end{array}$ & $\begin{array}{c}10,20 \pm \\
1,10 \\
\end{array}$ & $\begin{array}{c}9,80 \pm \\
1,10 \\
\end{array}$ & $\begin{array}{c}9,07 \pm \\
0,20 \\
\end{array}$ & $\begin{array}{c}8,90 \pm \\
0,10 \\
\end{array}$ & $\begin{array}{c}9,40 \pm \\
0,20 \\
\end{array}$ & $\begin{array}{c}9,70 \pm \\
0,40 \\
\end{array}$ & $\begin{array}{c}9,70 \pm \\
0,40 \\
\end{array}$ \\
\hline \multirow[t]{2}{*}{$\begin{array}{l}\text { Об'єм стопи, } \\
\text { ум. од. }\end{array}$} & $\begin{array}{c}1,02 \pm \\
0,09\end{array}$ & $\begin{array}{c}1,16 \pm \\
0,10\end{array}$ & $\begin{array}{c}1,14 \pm \\
0,11\end{array}$ & $\begin{array}{c}1,18 \pm \\
0,09\end{array}$ & $\begin{array}{c}1,17 \pm \\
0,11\end{array}$ & $\begin{array}{c}1,27 \pm \\
0,12\end{array}$ & $\begin{array}{c}1,28 \pm \\
0,09\end{array}$ & $\begin{array}{c}1,26 \pm \\
0,05\end{array}$ \\
\hline & \multicolumn{8}{|c|}{ Щури за сольового навантаження, $n=560$} \\
\hline $\begin{array}{l}\text { Поріг больової } \\
\text { чутливості, }\end{array}$ & $\begin{array}{c}9,07 \pm \\
0,02\end{array}$ & $\begin{array}{c}11,60 \pm \\
0,02^{*}\end{array}$ & $\begin{array}{c}11,50 \pm \\
0,02^{*}\end{array}$ & $\begin{array}{c}11,80 \pm \\
0,3^{*, \#}\end{array}$ & $\begin{array}{l}10,70 \pm \\
0,80^{\star}, \#\end{array}$ & $\begin{array}{l}10,80 \pm \\
0,30 *, \#\end{array}$ & \begin{tabular}{|l|}
$11,30 \pm$ \\
$0,20^{*}, \#$
\end{tabular} & $\begin{array}{l}11,10 \pm \\
0,40^{\star}, \#\end{array}$ \\
\hline $\begin{array}{l}\text { Об'єм стопи, } \\
\text { ум. од. }\end{array}$ & $\begin{array}{c}1,01 \pm \\
0,03\end{array}$ & $\begin{array}{l}1,14 \pm \\
0,04^{\star}\end{array}$ & $\begin{array}{l}1,11 \pm \\
0,01^{\star}\end{array}$ & $\begin{array}{l}1,16 \pm \\
0,05^{\star}\end{array}$ & $\begin{array}{l}1,26 \pm \\
0,06^{\star}\end{array}$ & $\begin{array}{l}1,32 \pm \\
0,08^{\star}\end{array}$ & $\begin{array}{l}1,32 \pm \\
0,07^{\star}\end{array}$ & $\begin{array}{l}1,46 \pm \\
0,10^{\star}\end{array}$ \\
\hline
\end{tabular}

Примітка. *p $\leq$ 0,05 порівняно з вихіднил значеннял у тварин даної групи, ${ }^{*} p \leq 0,05$ порівняно з показникол в інтактних тварин у відповідний терлін спостереження. 
сольового навантаження. Майже на $26 \%$ об’єм стопи у тварин через 81 добу від початку вживання сольового розчину перевищував значення, що реєструвалися на 21 добу АГ. Даний результат пояснюється, вочевидь, патологічним процесом - АГ, що, як відомо, може супроводжуватися набряком кінцівок через утримання води в організмі. Загалом, досліджуваний показник через 81 добу сольового навантаження був на 44,6 \% вищим за вихідне значення, тоді, як в інтактних тварин на цей термін спостереження він перевищував вихідне значення лише на 23,5 \%. Таким чином, АГ призводить до набряку кінцівок у щурів, що зростає зі збільшенням тривалості сольового навантаження. За вживання сольового розчину впродовж 81 доби набряків інших суглобів кінцівок (колінного та кульшового) і хвоста не спостерігалося.

Досліди щодо формування моделі АГ за тривалого сольового навантаження були проведені вісім разів (упродовж 2014-2019 рр.) у різні пори року, однак суттєвої різниці в досліджуваних показниках життєдіяльності тварин i функціонування серцево-судинної системи не виявлено.

Автори статті усвідомлюють, що результати проведених досліджень не надають вичерпної інформації щодо механізмів розвитку АГ за тривалого сольового навантаження, суті адаптаційних і компенсаторних процесів щодо пояснення фактів зниження кількості тварин з підвищеним АТ та розвитку брадикардії через 28 діб від початку формування моделі й їі гендерних особливостей. Передбачаються подальші дослідження, спрямовані на визначення кількості спожитого натрію, участі інших систем (зокрема, видільної, імунної тощо) у формуванні пропонованої моделі АГ.

\section{Висновки}

1. Пропонується нова модель АГ для дослідження ефективності та безпечності новосинтезованих сполук i лікарських препаратів за умов їхнього тривалого застосування, формування якої забезпечується сольовим навантаженням щурів упродовж 81 доби за умов заміни питної води на $1 \%$ розчин натрію хлориду з вільним доступом тварин до пиття.

2. Модель АГ формується незалежно від пори року в переважної більшості тварин (білих щурів) i характеризується суттєвим підвищенням АТ на 10-18\% у самиць і на 14-36 \% у самців, про що свідчать зміни зазначеного показника в різні терміни від початку до 80 доби сольового навантаження.

3. Значне зростання АТ спостерігається в 54,5-66,6 \% тварин упродовж тривалого часу (понад 60 діб), однак кількість тварин 3 підвищеним АТ знижується до 23,6 \% у період з 60 до 81 доби від початку сольового навантаження.

4. Подовження сольового навантаження понад 21 добу характеризується розвитком брадикардії, що повинно враховуватися за оцінки дії потенційних ліків та може бути використано для дослідження антиаритмічного (аритмогенного) впливу.

5. У білих щурів за умов тривалого сольового навантаження не відмічалося суттєвого порушення показників життєдіяльності різних органів і систем. Формування АГ не супроводжувалося загибеллю тварин, патологічною зміною маси тіла та коефіцієнта маси тимуса. Зміни інтегральних показників життєдіяльності тварин за умов подовження терміну сольового навантаження понад 21 добу були аналогічними до тих, що спостерігалися в щурів за формування «традиційної» (до 21 доби) моделі $\mathrm{A \Gamma}$.

6. На тлі формування АГ упродовж 21 доби, а також за умов збільшення терміну сольового навантаження до 81 доби знижується больова чутливість у щурів на 18-30\% .

7. АГ призводить до набряку кінцівок (суглобів стоп) у щурів, що зростає за тривалістю сольового навантаження і перевищує значення в інтактних щурів на $16 \%$ через 81 добу від початку формування моделі.

8. Запропонована модель АГ відрізняється простотою формування, еко- 
номічністю, відсутністю потреби в додатковій спеціальній підготовці фахівців і характеризується досягненням очікуваного ефекту (зростання АТ) у значної кількості щурів різної статі, можливістю відбору тварин з підвищеним АТ на будь-якому етапі формування патологічного про- цесу, можливістю їхнього утримання за звичайних лабораторних умов на стандартному режимі харчування. Отримані результати щодо клінічних проявів пропонованої моделі можуть бути використані для розробки шляхів оптимізації фармакологічної корекції $\mathrm{A \Gamma}$.

1. Моделювання артеріальної гіпертензії шляхом тривалого сольового навантаження та моніторинг функціонування серцево-судинної системи і динаміки інтегральних показників життєдіяльності у щурів (частина І). Н. М. Серединська, М. А. Мохорт, В. С. Хоменко та ін. Фармакологія та лікарська токсикологія. 2019.Т. 13, № 2. С. 83-92.

2. AHA Presidential Advisory. The Importance of Population-Wide Sodium Reduction as a Means to Prevent Cardiovascular Disease and Stroke. A Call to Action From the American Heart Association. L. J. Appel, E. D. Frohlich, J. E. Hall et al. Circulation. 2011. V. 123. P. 1138-1143.

3. Shah P. T., Maxwell K. D., Shapiro J. I. Dashing away hypertension: Evaluating the efficacy of the dietary approaches to stop hypertension diet in controlling high blood pressure. World $J$ Hypertens. 2015. V. 23, № 5. P. 119-128.

4. The central mechanism underlying hypertension: a review of the roles of sodium ions, epithelial sodium channels, angiotensin-aldosterone system, oxidative stress and endogenous digitalis in the brain. H. Takahashi, M. Yoshika, Y. Komiyama, M. Nishimura. Hypertension Research. 2011. V. 34, № 11. P. $1147-1160$.

5. Альдекеева А. С., Корнева Н. А., Зюбко Т. И. Влияние повышенного потребления $\mathrm{NaCl}$ на изменение уровня экспрессии Mrnk NAP-22 в почках у крыс линии SHR. Мед. академический ж-л. 2012. Т. 12, № 3. С. 64-66.

6. How $\mathrm{NaCl}$ raises blood pressure: a new paradigm for the pathogenesis of salt-dependent hypertension. M. P. Blaustein, F. H. H. Leenen, L. Chen et al. Am J Physiol Heart Circ Physiol. 2012. V. 302, № 5. P. H1031-H1049.

7. Bolivar J. J. Essential hypertension: an approach to its etiology and neurogenic pathophysiology. Int. J. Hypertens. 2013. V. 2013. 11 p.

8. Изменения сердечно-сосудистой системы у крыс, сопряженные с высоким потреблением хлорида натрия. О. Н. Береснева, М. М. Парастаева, Г. Т. Иванова и др. Артериальная гипертензия. 2014. Т. 20, № 5. С. 384-390.

9. Hashimoto J. Central Hemodynamics and Target Organ Damage in Hypertension. Tohoku J. Exp. Med. 2014. № 233. P. 1-8.

\section{Н. М.Серединська, В. С. Хоменко, О. М. Марченко, К. С. Марченко-Толста, Л. М. Киричок \\ Моделювання артеріальної гіпертензії шляхом тривалого сольового навантаження. Моніторинг функціонування серцево-судинної системи та динаміки інтегральних показників життєдіяльності в щурів (частина II)}

Запропоновано нову модель артеріальної гіпертензії (АГ), індуковану тривалим сольовим навантаженням. Розробка такої моделі базується на ролі натрію хлориду у функціонуванні життєво важливих органів і систем, у генезі АГ та її судинних порушень. Недостатня вивченість механізмів розвитку сольової АГ, фазності та тривалості патологічного стану за умов продовження сольового навантаження на тривалий час (до декількох місяців), особливостей дії різних лікарських засобів на тлі підвищеного споживання солі, стану серцево-судинної системи та інтегральних показників життєдіяльності зумовили мету дослідження.

Мета дослідження - вивчити стан серцево-судинної системи та динаміку інтегральних показників життєдіяльності в білих щурів за формування АГ шляхом тривалого сольового навантаження.

Формування нової моделі АГ забезпечувалося сольовим навантаженням щурів упродовж 81 доби за умов заміни води на 1 \% розчин натрію хлориду з вільним доступом тварин до пиття. За проведення динамічних досліджень встановлено, що модель АГ характеризується суттєвим підвищенням артеріального тиску на 10-18 \% у самиць і на 14-36 \% у самців, про що свідчать зміни зазначеного показника в різні терміни від початку до 81 доби сольового навантаження. Значне зростання артеріального тиску спостерігалося в 54,5-66,6 \% тварин упродовж 60 діб від початку сольового навантаження, водночас кількість тварин з підвищеним артеріальним тиском знижувалася до 23,6 \% через 81 добу від початку сольового навантаження. Продовження сольового навантаження понад 21 добу характеризувалося розвитком брадикардії. Збільшення терміну сольового навантаження в щурів не призводило до суттєвої зміни інтегральних показників життєдіяльності різних органів і систем, патологічної зміни маси тіла тварин і коефіцієнтів маси внутрішніх органів, у тому числі тимуса. За формування АГ на 18-30 \% знижувалася больова чутливість у щурів і спостерігався набряк кінцівок 
(суглобів і м'яких тканин стоп), що зростав з тривалістю сольового навантаження й перевищував значення в інтактних тварин понад 21 \% через 81 добу від початку формування моделі АГ.

Запропонована модель АГ відрізняється простотою формування, економічністю, досягненням відповідного ефекту в значної кількості щурів різної статі, можливістю відбору тварин з підвищеним артеріальним тиском на будь-якому етапі формування патологічного процесу, можливістю їхнього утримання за звичайних лабораторних умов, відсутністю загибелі тварин. Формування моделі АГ шляхом тривалого сольового навантаження не потребує спеціальної підготовки фахівців. Модель АГ за тривалого сольового навантаження пропонується для дослідження специфічної фармакологічної ефективності (гіпотензивної дії) і безпечності новосинтезованих сполук і відомих ліків за умов їхнього тривалого застосування.

Ключові слова: артеріальна гіпертензія, моделі, сольове навантаження, серцево-судинна система, інтегральні показники

\section{Н. Н. Серединская, В. С. Хоменко, О. Н. Марченко, Е. С. Марченко-Толстая, Л. М. Киричок \\ Моделирование артериальной гипертензии путем длительной солевой нагрузки. Мониторинг функционирования сердечно-сосудистой системы и динамики интегральных показателей жизнедеятельности у крыс (часть II)}

Предложена новая модель артериальной гипертензии (АГ), индуцированная длительной солевой нагрузкой. Разработка такой модели базируется на роли натрия хлорида в функционировании жизненно важных органов и систем, в генезе АГ и ее сосудистых нарушений. Недостаточная изученность механизмов развития солевой АГ, фазности и длительности патологического состояния при продлении солевой нагрузки на срок до нескольких месяцев, особенностей действия разных лекарств на фоне повышенного употребления соли, состояния сердечно-сосудистой системы и интегральных показателей жизнедеятельности обусловили цель исследования.

Цель исследования - изучить состояние сердечно-сосудистой системы и динамику интегральных показателей жизнедеятельности у белых крыс при формировании АГ путем длительной солевой нагрузки.

Формирование новой модели АГ осуществлялось путем солевой нагрузки в течение 80 суток при замене воды на 1 \% раствор натрия хлорида со свободным доступом к питью. При проведении динамических исследований установлено, что модель АГ характеризуется существенным повышением артериального давления на 10-18 \% у самок и на 14-36 \% у самцов, о чем свидетельствуют изменения данного показателя в разные сроки от начала до 81 суток солевой нагрузки. Существенное повышение артериального давления наблюдалось у 54,5-66,6 \% животных в течение длительного времени, однако количество крыс с повышенным артериальным давлением знижалось до 23,6 \% через 81 сутки после начала солевой нагрузки. Продление солевой нагрузки свыше 21 суток характеризовалось развитием брадикардии у белых крыс, но не приводило к существенным изменениям интегральных показателей функционирования различных органов и систем, уменьшению массы тела и коэффициентов массы внутренних органов, в том числе тимуса. При формировании АГ на 18-30 \% понижалась болевая чувствительность у крыс и наблюдался отек конечностей (суставов и мягких тканей стоп), который возрастал при увеличении длительности солевой нагрузки и превышал значения у интактных животных более, чем на 16 \% через 81 сутки от начала формирования модели АГ.

Предложенная модель АГ отличается простотой формирования, экономичностью, достижением соответственного эффекта у значительного числа белых крыс разного пола, возможностью отбора животных с повышенным артериальным давленим на любом этапе формирования патологического процесса и их содержания в обычных лабораторных условиях, отсутствием гибели животных. Формирование модели АГ при длительной солевой нагрузке не требует специальной подготовки специалистов. Разработанная модель АГ предлагается для исследования специфической фармакологической эффективности (гипотензивного действия) и безопасности новосинтезированных соединений и известных лекарственных средств при их длительном применении.

Ключевые слова: артериальная гипертензия, модели, солевая нагрузка, сердечно-сосудистая система, интегральные показатели

\section{N. M. Seredinska, V. S. Khomenko, O. M. Marchenko, K. S. Marchenko-Tolsta, L. M. Kirichok \\ Modeling of arterial hypertension by prolonged salt loading. Monitoring of the functioning of the cardiovascular system and the dynamics of integral vital signs in rats (part II)}

A new model of arterial hypertension $(\mathrm{AH})$, induced by a long salt loading, is proposed. The development of such a model is based on the role of sodium chloride in the functioning of vital organs and systems and in the genesis of hypertension and its vascular disorders. Insufficient study of the mechanisms of development of salt $\mathrm{AH}$, phase and duration of the pathological state under prolongation of the salt load 
for a period of up to several months, features of various drugs action on the background of increased salt intake, functioning of the cardiovascular system and the dynamics of integral vital signs in rats determined the purpose of the study.

The purpose of the study is to investigate the state of the cardiovascular system and the dynamics of integral vital signs in white rats during $\mathrm{AH}$ formation by prolonged salt loading. The formation of a new model of $\mathrm{AH}$ was provided by salt loading of rats for 81 days by water replacement with a $1 \%$ solution of sodium chloride and free access of animals to drink. While conducting dynamic studies it was established that $\mathrm{AH}$ model is characterized by a significant increase in blood pressure by $10-18 \%$ in females and $14-36 \%$ in male rats, as evidenced by changes of this indicator in different periods from the beginning to the $81^{\text {th }}$ days of salt loading. Significant increase in blood pressure was observed in $54,5-66,6 \%$ of animals for a long time, while the number of animals with high blood pressure decreased to 23,6 \% after 81 days. The prolongation of salt loading over 21 days was characterized by the development of bradycardia in white rats, but did not lead to significant changes in the integral indicators of the functioning of various organs and systems, decrease of body weight and mass coefficients of internal organs, including thymus. During the formation of $\mathrm{AH}$, pain sensitivity in rats decreased by $18-30 \%$ and paw edema (joints and soft tissues of the paw) was observed, which increased under prolongation of salt load and exceeded the values of intact animals by $16 \%$ after 81 day of $\mathrm{AH}$ formation.

The proposed $\mathrm{AH}$ model is differs by simplicity of formation, economical, the achievement of a corresponding effect in a significant number of white rats of different sexes, the possibility of selecting animals with high blood pressure at any stage of pathological process formation and their keeping in normal laboratory conditions, the absence of animals death. Formation of the $\mathrm{AH}$ model by prolonged salt loading does not require special professional training. The $\mathrm{AH}$ model induced by long-term salt loading is proposed for study the specific pharmacological efficacy (hypotensive effect) and safety of newly synthesized compounds and known drugs under their long-term use.

Key words: arterial hypertension, model, salt loading, cardiovascular system, integral vital signs

Надійшла: 28 березня 2019 р.

Прийнята до друку: 23 травня 2019 р.

Контактна особа: Серединська Н. М., ДУ «Інститут фармакології та токсикології НАМНУ», буд. 14, вул. Антона Цедіка, м. Київ, 03057. Тел: + 380444564256. 